\title{
Synthesis and properties of dinitrobenzamido-TEMPO derivatives
}

\author{
Mădălina Tudose, ${ }^{a}$ Petre Ioniță, ${ }^{b}$ Florin Dumitraşcu, ${ }^{c}$ Constantin Drăghici, ${ }^{c}$ \\ Miron T. Căproiu, ${ }^{d}$ Irina C. Covaci, ${ }^{a}$ Titus Constantinescu, ${ }^{c}$ Mircea D. Banciu, ${ }^{\mathrm{e}}$ and \\ Alexandru T. Balaban ${ }^{f}$
}

a Institute 'I. G. Murgulescu' of Physical Chemistry of the Romanian Academy, Splaiul Independentei 202, Laboratory of Supramolecular Chemistry and Interphase Processes, 060021 Bucharest, Romania

E-mail: madalina tudose2000@yahoo.com

${ }^{b}$ Department of Chemistry, University of York, Heslington, York, UK YO10 5DD

E-mail:pi4@york.ac.uk

${ }^{c}$ Department of NMR, Institute 'C. D. Nenitzescu' of Organic Chemistry of Romanian Academy, Splaiul Independentei 202B, 060021, Bucharest, Romania

E-mail:fdumitra@,cco.ro

${ }^{d}$ Department of NMR, Institute 'C. D. Nenitzescu' of Organic Chemistry of Romanian Academy, Splaiul Independentei 202B, Bucharest, Romania

E-mail: mtc@,cco.ro

${ }^{e}$ Department of Organic Chemistry, Polytechnic University Bucharest, Splaiul Independentei 313, 060021 Bucharest, Romania

E-mail: dmbanciu@chim.upb.ro

${ }^{f}$ Department of Marine Sciences, Texas A\&M University at Galveston, 5007 Avenue U, Galveston, TX 77551, USA

E-mail: balabana@,tamug.edu

(received 4 May 05; accepted 15 Aug 05; published on the web 22 Aug 05)

\begin{abstract}
4-Chloro-3,5-dinitrobenzoic acid (1a) and 2-chloro-3,5-dinitrobenzoic acid (1b) were converted into the corresponding acid chlorides (2a and $\mathbf{2 b}$ ) and these were reacted first with an equimolar amount of 4-amino-2,2,6,6-tetramethylpiperidine-N-oxyl radical (4-amino-TEMPO) to afford monoradicals $\mathbf{3 a}, \mathbf{3 b}, \mathbf{5 a}$, and $\mathbf{5 b}$ and then either (i) with methoxyamine to yield hetero-diradicals $\mathbf{6} \mathbf{a}$ and $\mathbf{6 b}$, or (ii) with a second mole of 4-amino-TEMPO to afford homo-diradicals $\mathbf{4 a}$ and $\mathbf{4 b}$. The reaction of 3a with 1,3-bis(aminooxy)propane gave the homo-diradical 7a. These reaction products are stable mono- or di-radicals as evidenced by their ESR spectra at various temperatures. The above reaction products can participate as oxidizers in redox reactions, and they afford deep-colored anions with inorganic or organic bases.
\end{abstract}

Keywords: Dinitrobenzamido-TEMPO derivatives, mono- and diradicals (homo- and heterodiradicals), paramagnetic-chromogenic derivatives, RES, oxidizing properties 


\section{Introduction}

We designed a synthetic approach to stable monoradicals and diradicals starting from chlorodinitrobenzoic acid chlorides, which can undergo nucleophilic substitutions with markedly different rates allowing the selective preparation of target molecules.

The notation used in the following will denote the series of 2,6-dinitrophenyl compounds with letter $\mathbf{a}$, and the 2,4-dinitrophenyl-substituted compounds with letter $\mathbf{b}$. A TEMPO radical (2,2,6,6-tetramethylpiperidine-N-oxyl) will be denoted by the letter $\mathrm{T}$ with a dot above it, representing the odd electron.

Starting with the commercially available 4-chloro-3,5-dinitrobenzoic acid (1a) and 2-chloro3,5-dinitrobenzoic acid (1b), the corresponding acid chlorides (2a and $\mathbf{2 b}$ ) were prepared. Monoradicals (3a and 3b) incorporating one TEMPO fragment (2,2,6,6-tetramethylpiperidine-Noxyl) attached via an amidic bond were then obtained by reaction with an equimolar amount of the 4-amino-2,2,6,6-tetramethylpiperidine-N-oxyl radical (4-amino-TEMPO). Then, by an $\mathrm{S}_{\mathrm{N}} \mathrm{Ar}$ reaction, ${ }^{1,2}$ the aromatic-bonded chlorine atom was replaced by reaction with either methoxyamine yielding monoradicals $\mathbf{5 a}$ and $\mathbf{5} \mathbf{b},^{3-5}$ or with a second molecule of 4-aminoTEMPO affording homo-diradicals $\mathbf{4 a}$ and $\mathbf{4 b}$. The latter compounds can also be obtained in one step from $\mathbf{3 a}$ or $\mathbf{3 b}$ with an excess of 4-amino-TEMPO.

A different type of homo-diradical (7a) was obtained from two moles of $\mathbf{3 a}$ by reaction with one mole of 1,3-bis(aminooxy)propane. ${ }^{5}$ In principle, this compound could be oxidized to a hetero-tetra-radical but this reaction has not yet been tried.

In turn, oxidation of the aryl-N-methoxyamino group ${ }^{6-12}$ of 5a with lead dioxide affords a persistent hetero-diradical 6a free radical possessing an aminyl and a nitroxidic group. All these structures can be seen in Scheme 1. From them, only compound 3a was reported earlier. ${ }^{13}$<smiles>O=C(Cl)c1cc([N+](=O)[O-])c(Cl)c([N+](=O)[O-])c1</smiles>

$2 a$<smiles>[3H]NC(=O)c1cc([N+](=O)[O-])c(Cl)c([N+](=O)[O-])c1</smiles>

$3 a$<smiles>C[Te]</smiles><smiles>[3H]NC(=O)c1cc([N+](=O)[O-])c(NOC)c([N+](=O)[O-])c1</smiles>

$5 a$

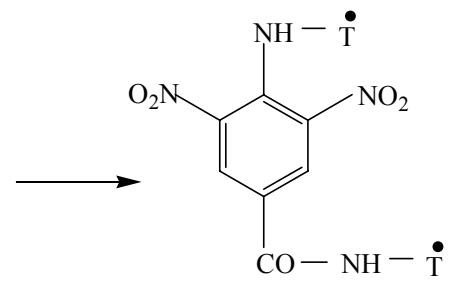

$4 a$

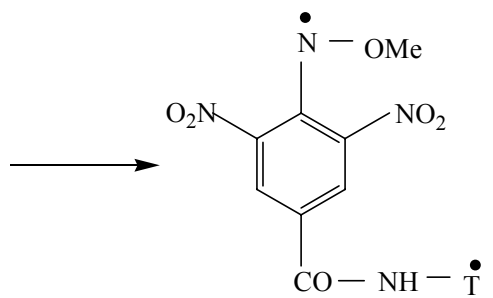

$6 a$ 


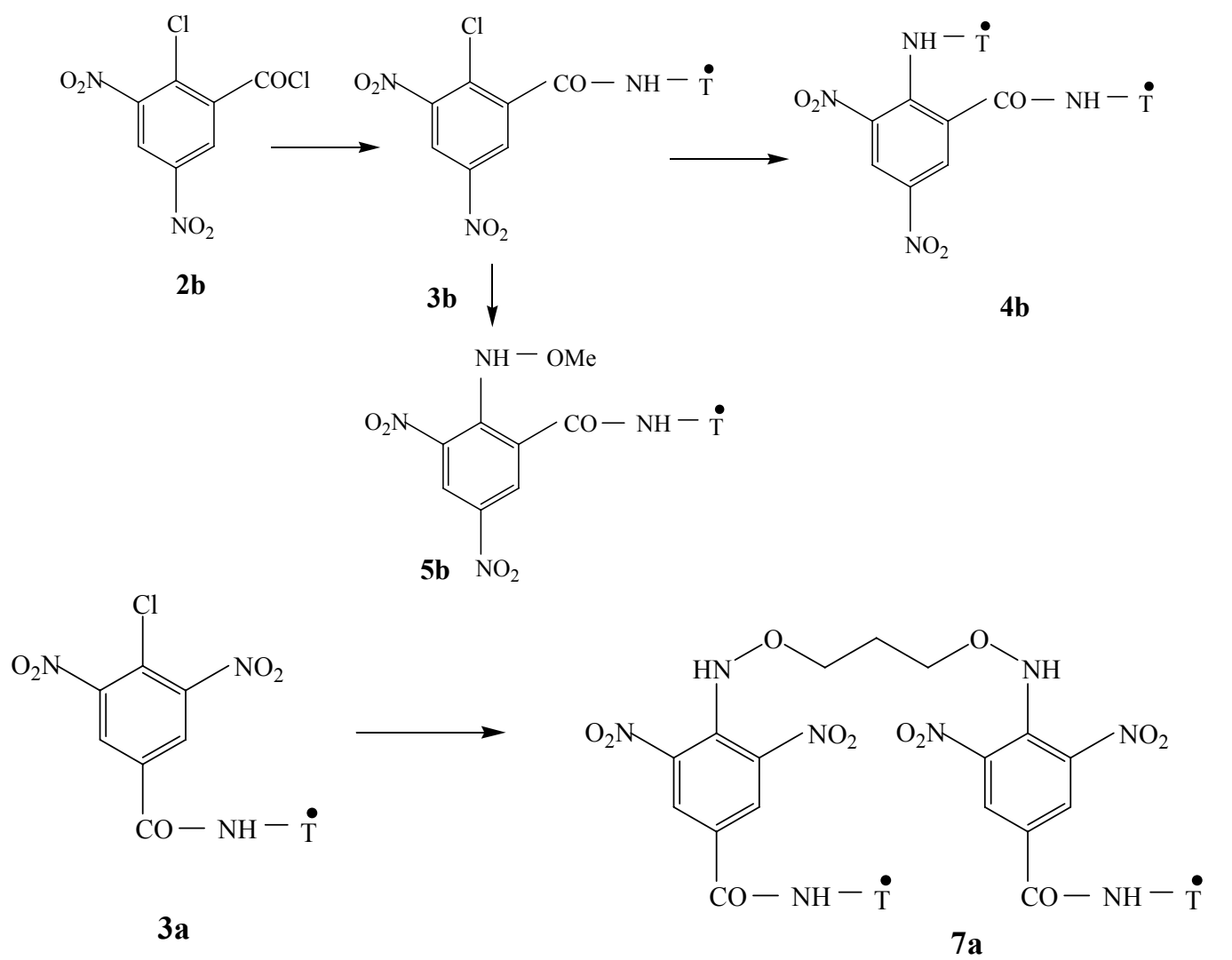

\section{Scheme 1}

\section{Results and Discussion}

The stability of nitroxides and of push-pull aminyls is nicely explained by Linnett's assumption ${ }^{14,15}$ about a higher bond order than 1 between the two heteroatoms due to the presence of two opposite spins ( $\alpha$ and $\beta$ ). As seen in Scheme 2, every atom has a closed electronic shell with opposite spins. Unlike the resonance-theoretical explanation, Linnett's theory implies a threeelectron bond between the two heteroatoms. Evidence for such a higher bond order was obtained by variable temperature ESR spectroscopy of 1-arenesulfonyl-2,2-bis(3,5-di-tertbutylphenyl)hydrazyl: the rotation barrier between the hydrazinic nitrogens was found to be substantial, leading to magnetic non-equivalence between the two 3,5-di-tert-butylphenyl groups. ${ }^{16}$ One should bear in mind that the polynitrophenyl-nitrogen bond in all neutral compounds (and even more in the corresponding anions, as will be discussed in one of the next sections) also has a partial double bond character. 
Resonance theory

Nitroxides
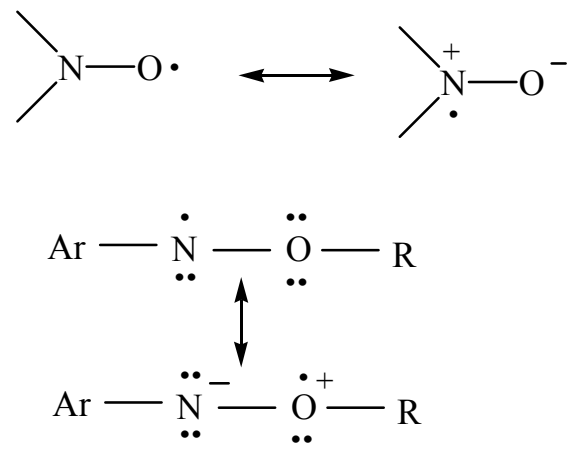

Linnett's theory<smiles></smiles>

\section{Scheme 2}

\section{ESR Spectra}

Figures 1 - 3 present room-temperature ESR spectra of some of the compounds discussed above, and Figure 4 shows one low-temperature ESR spectrum. Values of hyperfine coupling constants are presented in Table 1.

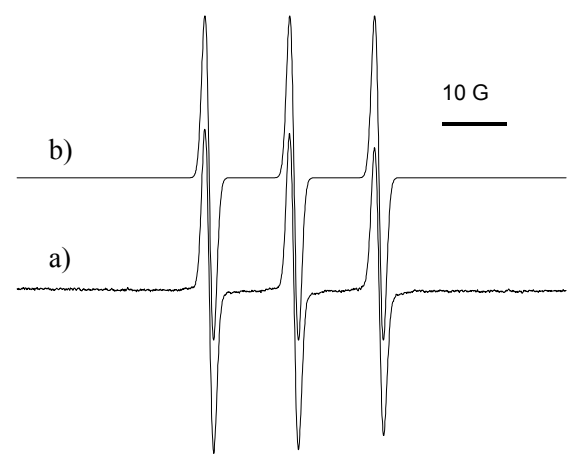

Figure 1. Experimental (a) and simulated (b) Figure 2. Experimental (a) and simulated (b) ESR spectra of compound $\mathbf{4 a}$, at room temperature.

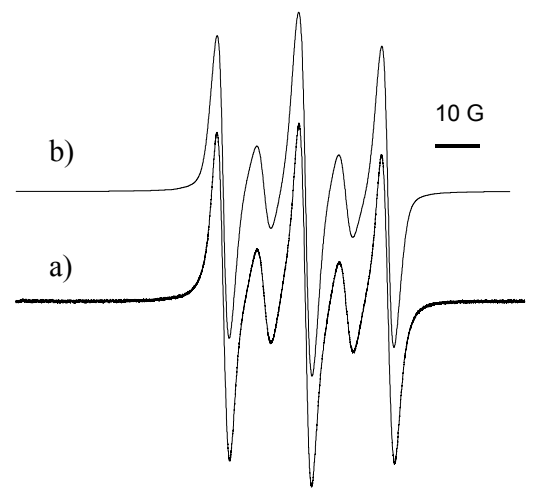

ESR spectra of compound $\mathbf{4 b}$, at room temperature. 


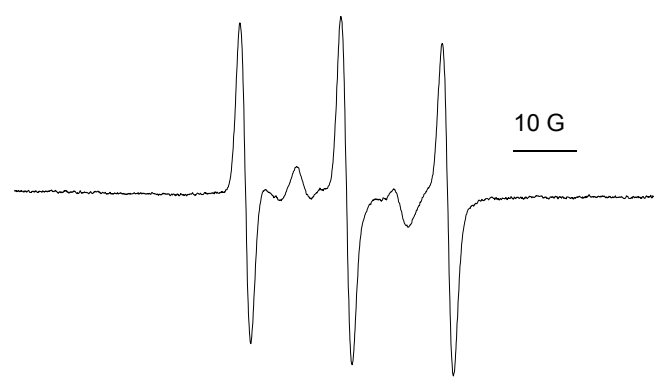

Figure 3. Experimental ESR spectrum of compound 6a, at room temperature.

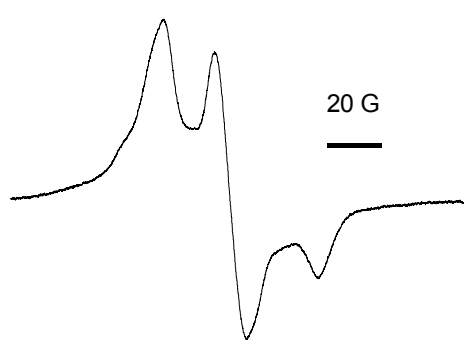

Figure 4. Low temperature experimental ESR spectra of compound $\mathbf{4 b}$ at $120 \mathrm{~K}$.

Table 1. Hyperfine coupling constants $\left(\mathrm{a}_{\mathrm{N}}\right)$ for $\mathbf{3 a}, \mathbf{b} ; \mathbf{4 a}, \mathbf{b} ; \mathbf{5 a}, \mathbf{b} ; \mathbf{6} \mathbf{a} ; \mathbf{7 a}$; and $\mathbf{9}$

\begin{tabular}{|c|c|c|}
\hline Compound & Solvent $^{\mathrm{a}}$ & $\mathrm{a}_{\mathrm{N}}$ (Gauss) \\
\hline Chloro-monoradical 3a & Toluene & 15.44 \\
\hline Chloro-monoradical $\mathbf{3 b}$ & Methylene chloride & 15.70 \\
\hline Methoxyamino-monoradical 5a & Toluene & 15.44 \\
\hline Methoxyamino-monoradical $\mathbf{5 b}$ & Methylene chloride & $8.19 ; 7.34$ \\
\hline Homo-diradical 4a & Toluene & 15.46 \\
\hline Homo-diradical $\mathbf{4 b}$ & Methylene chloride & 15.72 \\
\hline Hetero-diradical $\mathbf{6 a}$ & Toluene $^{\mathrm{c}}$ & $15.46 ; \sim 10$ \\
\hline Homo-diradical 7a & Methylene chloride & 15.66 \\
\hline Homodiradical-anion $8 \mathbf{a}$ (from 4a) & Toluene ${ }^{b}$ & 15.46 \\
\hline Homodiradical-anion $\mathbf{8 b}$ (from $\mathbf{4 b}$ ) & Methylene chloride $^{b}$ & 15.75 \\
\hline Homodiradical-anion 9a (from 7a) & Methylene chloride ${ }^{b}$ & 15.72 \\
\hline
\end{tabular}

${ }^{a}$ Deoxygenated, room temperature spectra.

${ }^{\mathrm{b}}$ Compounds $4 \mathbf{a}$ or $7 \mathbf{a}$ in the presence of diethylamine.

${ }^{\mathrm{c}}$ Compound $\mathbf{6 a}$ in the presence of $\mathrm{PbO}_{2}$.

Mono-radicals 3a, 3b, 5a, 5b, and $\mathbf{6 a}$ present at room temperature the usual ESR triplet for TEMPO nitroxides as in Figure $1 .{ }^{17}$ The homo-diradical $\mathbf{4 b}$ with ortho-connected TEMPO residues is the only one to show a difference in ESR coupling constants indicating spin interaction (Figure 2). ${ }^{17} \mathrm{At}-153^{\circ} \mathrm{C}$ this frozen diradical shows line broadening (Figure 4), but no clear-cut evidence for a triplet state. The hetero-diradical 6a (Figure 3) also presents signs of spin interaction, but at room temperature the ESR spectrum changes during a few minutes into a normal triplet, probably due to the lower stability of oxyaminyl free radicals. In the ESR spectrum of the homo-diradical 7a at low temperature one observes a line broadening similar to that displayed in Figure 3.

One should note that we did not succeed to obtain ESR evidence for a hetero-diradical $\mathbf{6 b}$. One can conjecture that it would cyclize intramolecularly to a benzopyrazolone. An analogous 
cyclization can be imagined for 6a yielding a benzofuroxan, explaining perhaps the unusual aspects of its ESR spectrum (Figure 3).

\section{Reactions with inorganic or organic bases}

Methoxyamines $\mathbf{4 a , b}$ and $\mathbf{7 a}$ are acidic, like $\mathrm{N}$-alkyl-polynitroanilines, ${ }^{3-5}$ reacting instantaneously and reversibly with inorganic or organic bases when they afford coloured anions 8a,b and 9a having a more pronounced electronic delocalization (Scheme 3). The observed colours and the corresponding $\lambda_{\max }$ values are displayed in Table 2.

Table 2. Qualitative reactions of the acidic compounds $\mathbf{4 a , b}$ and $\mathbf{7 a}$ with bases and proteins (molar ratio: base:acidic compound $=3: 1$ )

\begin{tabular}{|c|c|c|c|}
\hline \multirow{2}{*}{ Bases and proteins } & \multicolumn{3}{|c|}{ Colors of radical-anions $8 \mathrm{a}, \mathrm{b}$ and $9 \mathrm{a}$} \\
\hline & $\mathbf{4 a} \rightarrow \mathbf{8 a}$ & $4 b \rightarrow 8 b$ & $\mathbf{7 a} \rightarrow \mathbf{9 a}$ \\
\hline Inorganic bases: $:^{\mathrm{a}}(\mathrm{LiOH}, \mathrm{NaOH}, \mathrm{KOH})$ & Blue $^{d}$ & $\operatorname{Red}^{\mathrm{e}}$ & Blue $^{f}$ \\
\hline $\begin{array}{l}\text { Organic bases: }{ }^{\mathrm{b}} \text { (piperidine, pyrrolidine, } \\
\text { morpholine, ethylenediamine, triethylamine, } \\
\text { Kryptofix K22 }{ }^{*} \text { or K } 222^{* *} \text { ) }\end{array}$ & Blue $^{d}$ & $\operatorname{Red}^{\mathrm{e}}$ & Blue $^{f}$ \\
\hline $\begin{array}{c}\text { Basic amino acids: }:^{\mathrm{a}} \text { (L-ornitine, L-lysine, } \\
\text { arginine) }\end{array}$ & Blue $^{d}$ & $\operatorname{Red}^{\mathrm{e}}$ & Blue $^{f}$ \\
\hline $\begin{array}{c}\text { Proteins and enzimes: }{ }^{\mathrm{c}} \\
\text { Bovine serum albumin (Merck, fraction V) } \\
\text { Peroxidase (Merck, } 10000 \mathrm{U} / \mathrm{mg}) \\
\text { Lysozyme (Merck, } 15000 \mathrm{E} / \mathrm{mg})\end{array}$ & Blue $^{d}$ & $\operatorname{Red}^{\mathrm{e}}$ & Blue $^{f}$ \\
\hline
\end{tabular}

1,7,10,16-Tetraoxa-4,13-diazacyclooctadecane.

4,7,13,16,21,24-Hexaoxa-1,10-diazabicyclo[8.8.8]hexacosane.

$\mathrm{L} / \mathrm{L}$ (water with base/methylene chloride with acidic compound).

In methylene chloride.

In water with $0.05-0.1 \mathrm{~mL}$ of ethanol solution with acidic compound.

$\lambda_{\max }=561 \mathrm{~nm} .{ }^{\text {e) }} \lambda_{\max }=488 \mathrm{~nm} .{ }^{\text {f) }} \lambda_{\max }=573 \mathrm{~nm}$.

The paramagnetic and chromogenic properties of compounds $\mathbf{4 a}, \mathbf{4 b}$ and $\mathbf{7 a}$ make them possible candidates for applications in analytical and bioanalytical chemistry.

\section{Mass spectra}

In the ESI mass spectra of compounds 3-5 one observes always the molecular peak as the base peak. An interesting observation was made for compounds $\mathbf{3 a}$ and $\mathbf{3 b}$, namely that in addition to the molecular peak one observes the peaks due to the hydrochloride $(M+36)$. In the mass 
spectra of methoxyamino compounds $\mathbf{5 a}$ and $\mathbf{5 b}$ one observes low-intensity fragment peaks at $\mathrm{m} / \mathrm{z}=\mathrm{M}-15$ due to loss of the methyl group.<smiles>[3H]NC(=O)c1cc(OC)c(NC(=O)c2cc([N+](=O)[O-])c(N(C)[IH+])c([N+](=O)[O-])c2)c([N+](=O)[O-])c1</smiles>

$5 \mathbf{a}$

$8 \mathbf{a}$<smiles>[3H]NC(=O)Nc1c(C(=O)OC)cc([N+](=O)[O-])cc1[N+](=O)[O-]</smiles>

$\mathbf{5 b}$

$\mathbf{8 b}$<smiles>[3H]NC(=O)c1cc(N(C)OCCCON(C)c2c([N+](=O)[O-])cc(C(=O)N[3H])cc2[N+](=O)[O-])c(NOCCCONc2c([N+](=O)[O-])cc(C(=O)N[3H])cc2[N+](=O)[O-])c([N+](=O)[O-])c1</smiles>

$7 \mathbf{a}$

9a

\section{Scheme 3}

\section{Quenching effects and redox reactions}

The substances described in this study (3-7) have a quenching effect on fluorescent compounds such as anthracene, carbazole, phenothiazine, tryptophan. ${ }^{18,19}$ Again, possible applications may be envisaged.

Oxidizing properties of TEMPO radicals are known, ${ }^{20-22}$ and such compounds may be used for mild oxidations of thiols, amines, primary or secondary alcohols, It is also known that in 
acidic medium TEMPO derivatives 10 undergo disproportionation yielding oxoammonium (11) and hydroxylamine salts (12), as indicated in Scheme $4 .^{21,22}$<smiles>[R]C1CC(C)(C)N(O)C(C)(C)C1</smiles>

10<smiles>[R]C1CC(C)(C)[N+](=O)C(C)(C)C1</smiles>

11<smiles>[R]C1CC(C)(C)[N+]([O])(O)C(C)(C)C1</smiles>

12

Scheme 4. Disproportionation of TEMPO derivatives $\mathbf{1 0 .}$

Compounds 3a,b-7a were tested as oxidants for compounds $\mathbf{1 3 a}-\mathbf{1 3 f}{ }^{23,24}$ in the absence (no reaction) and in the presence of para-toluenesulfonic acid ${ }^{21}$ (when the blue-violet betainic structures 14a-14f occurred). ${ }^{23,24}$ In the reaction with 2,2-diphenyl-1-picrylhydrazine (DPPHine, 15, $\mathrm{R}=\mathrm{H}$ ), compounds $\mathbf{3 a}, \mathbf{b}$ and $\mathbf{5 a}, \mathbf{b}$ afforded in the presence of para-toluenesulfonic acid the violet 2,2-diphenyl-1-picrylhydrazyl free radical (DPPH) $(\mathbf{1 6}, \mathrm{R}=\mathrm{H})$, together with traces of its nitro-derivative $\left(\mathbf{1 6}, \mathrm{R}=\mathrm{NO}_{2}\right)$. This secondary product is formed by disproportionation ${ }^{25-29}$ of DPPH $(\mathbf{1 6}, \mathrm{R}=\mathrm{H})$ in methylene chloride in the presence of para-toluenesulfonic acid, ${ }^{29,30}$ as checked by TLC.

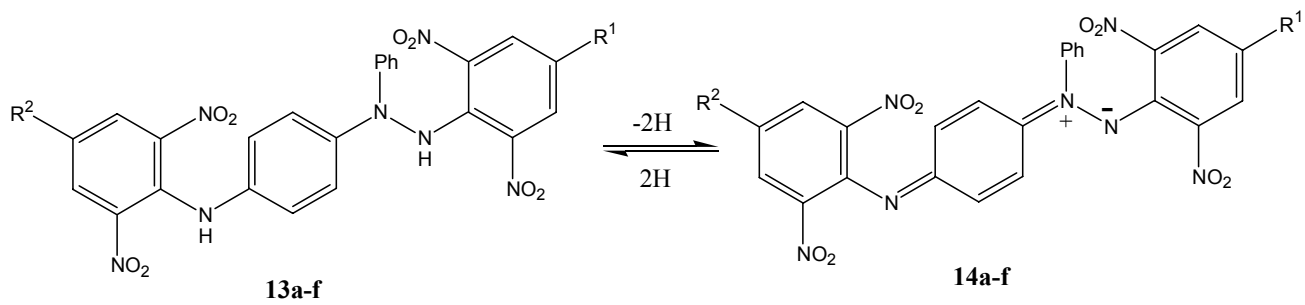
a $\mathrm{R}^{1}=\mathrm{R}^{2}=\mathrm{NO}_{2}$
b $\mathrm{R}^{1}=\mathrm{NO}_{2} ; \mathrm{R}^{2}=\mathrm{CN}$
c $\mathrm{R}^{1}=\mathrm{CN} ; \mathrm{R}^{2}=\mathrm{NO}_{2}$
d $\mathrm{R}^{1}=\mathrm{R}^{2}=\mathrm{CN}$
e $\mathrm{R}^{1}=\mathrm{NO}_{2} ; \mathrm{R}^{2}=\mathrm{COOMe}$
f $\mathrm{R}^{1}=\mathrm{NO}_{2} ; \mathrm{R}^{2}=\mathrm{CF}_{3}$

Scheme 5. Redox reactions of compounds 13a-13f and 14a-14f. 


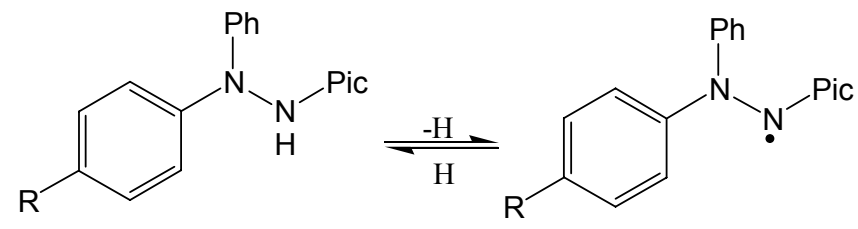

15

16

Scheme 6. Redox reactions of DPPH and DPPH-ine (15 and 16, R = H).

The positive results on using compounds $\mathbf{3 a}$ and $\mathbf{3 b}$ as oxidizing agents prompted us to immobilize them by an $\mathrm{S}_{\mathrm{N}} \mathrm{Ar}$ reaction on solid support (aminopropylsilica gel, Lichrospher ${ }^{\mathrm{R}}$, $100 \mathrm{NH}_{2}, 5 \mu \mathrm{m}$, Merck). Working with solutions of 13a-13f or 15 in the presence of paratoluenesulfonic acid, a suspension of our products on solid support afforded the same oxidation products.

\section{Conclusions}

The stable monoradicals $\mathbf{3 a}, \mathbf{b}$ formed from 4-amino-TEMPO and dinitrobenzoyl chlorides $\mathbf{2 a , b}$ have a reactive chloro substituent that can be substituted by nucleophiles. Reaction of $\mathbf{3 a}$ with methoxyamine yields the monoradical $4 \mathbf{a}$ which can be oxidized to the hetero-diradical $6 \mathbf{6}$. Reaction of 3a,b with 4-amino-TEMPO affords the homo-diradicals 4a,b. Another homodiradical, 7a, was formed from 3a and 1,3-bis(aminooxy)propane. Whereas most of the compounds described in the present study exhibit three lines in their ESR spectra, the homodiradical 4b with ortho-connected chains ending in TEMPO groups presents a 5-line ESR spectrum that broadens at low temperature.

Compounds 4a and 7a yield blue anions on treatment with inorganic or organic bases, whereas compound $\mathbf{4 b}$ affords a red anion under the same conditions. Compounds 3-7 quench the fluorescence of aromatic compounds and oxidize push-pull hydrazinic derivatives such as 2,2-diphenyl-1-picrylhydrazine.

\section{Experimental Section}

General Procedures. NMR Spectra were recorded with a Varian Gemini $300 \mathrm{MHz}$ instrument. Electronic absorption spectra were obtained with a UV-Vi Hitachi U-3000. IR spectra were obtained with a Paragon 1000 FT-IR and EPR spectra were recorded with a Jeol Jes-RE1X or Bruker ESP-300E instrument. Electrospray ionization mass spectra (ESI-MS) were recorded on a Finnigan LCQ mass spectrometer.

Commercially available starting materials were the two 4- and 2-chloro-3,5-dinitrobenzoic acids (1a and 1b, respectively) from Aldrich, 4-amino-TEMPO (Aldrich), DPPH (Aldrich) and 
$\mathrm{N}$-methoxyamine or O-methylhydroxylamine (Merck). Silica gel glass plates $60 \mathrm{~F}_{254}$ (Merck) were employed for TLC separations. The preparation of $\mathrm{DPPH}_{2}(\mathbf{1 5}, \mathrm{R}=\mathrm{H})$, of compounds $\mathbf{1 3 a}-$ $\mathbf{f}^{23,24}$ and of 1,3-bis(aminooxy)propane dihydrochloride was prepared as described earlier. ${ }^{5}$

4- and 2-Chloro-3,5-dinitrobenzoyl chloride (2a and $\mathbf{2 b}$, respectively) were prepared from the corresponding acids in benzene $(5 \mathrm{~mL} / \mathrm{g}$ of acid) with thionyl chloride $(0.8 \mathrm{ml} / \mathrm{g})$ and $N, N-$ dimethylformamide (DMF, 2 drops/g). After refluxing for $1 \mathrm{~h}$ the volatile products were evaporated under reduced pressure leaving the crystalline products in quantitative yield: pale yellow solids, easily soluble in chloroform or dichloromethane, in which the acids are insoluble.

2a. ${ }^{1} \mathrm{H}-\mathrm{NMR}\left(\mathrm{CDCl}_{3}\right.$, ppm): 8.70 (s, 2H, H-2, H-6). ${ }^{13} \mathrm{C}-\mathrm{NMR}\left(\mathrm{CDCl}_{3}, \mathrm{ppm}\right): 127.3$ (C-4); 128.9 (C-2, C-6); 133.3 (C-1);149.8 (C-3, C-5); 164.3 (COCl).

2b. ${ }^{1} \mathrm{H}-\mathrm{NMR}\left(\mathrm{CDCl}_{3}\right.$, ppm, J, Hz): 8.80 (d, 1H, 2.5, H-6); 8.96 (d, 1H, 2.5, H-4). ${ }^{13} \mathrm{C}-\mathrm{NMR}$ $\left(\mathrm{CDCl}_{3}, \mathrm{ppm}\right)$ : 123.2 (C-3); 129.1 (C-5); 131.6 (C-1); 137.6 (C-6); 145.6 (C-2); 149.8 (C-2); 149.8 (C-4); 162.8 (COCl).

4- and 2-Chloro-3,5-dinitro- $N$-(4-(2,2,6,6-tetramethyl-piperidine-1-oxyl)-benzamide)) (3a and $\mathbf{3 b}$, respectively). were obtained similarly to ref. ${ }^{31}$ from an ice-cold solution of 4-aminoTEMPO ( $1 \mathrm{~g}$ in $10 \mathrm{~mL}$ water) into which an ice-cold solution of acid chloride $(1 \mathrm{~g}$ in $2.5 \mathrm{~mL}$ of acetone) was added in one portion under strong stirring in an ice-salt cooling bath. After 45 seconds, $50 \mathrm{~mL}$ of $1 \mathrm{M}$ hydrochloric acid was added in a single portion and the stirring was continued for $30 \mathrm{~min}$. keeping the cooling bath. The yellow-orange solid was filtered off through $\mathrm{a}_{3}$ sintered glass filter, washed with $1 \mathrm{M}$ cold hydrochloric acid and then with water, suspended in $30 \mathrm{~mL}$ of $10 \%$ aqueous sodium hydrogen carbonate, stirred for $30 \mathrm{~min}$., filtered off and washed with water. After $24 \mathrm{~h}$ drying in a desiccator over anhydrous calcium chloride the crude product was dissolved in methylene chloride, alumina (Merck, Brockmann activity I) was added, the suspension was stirred for $30 \mathrm{~min}$. and filtered. The solvent was removed under vacuum, and the purity (determined by TLC on silicxa gelGF254 glass plates with $\mathrm{CH}_{2} \mathrm{Cl}_{2}$-diethyl ether 8:2 $\mathrm{v} / \mathrm{v}$ ) was satisfactory for further use. For higher purity, preparative TLC was used under similar conditions, the product was extracted in a Soxhlet apparatus, and the solvent was removed under vacuum.

3a. yield 44\%; mp.236-37 ${ }^{\circ} \mathrm{C}$ (lit. $\left.{ }^{13} 236-238^{\circ} \mathrm{C}\right)$; ESI-MS m/z $\left([\mathrm{M}]^{+}\right)=398$. Elem. analysis: calcd. for $\mathrm{C}_{16} \mathrm{H}_{20} \mathrm{ClN}_{4} \mathrm{O}_{6}$ : C, 48.07\%; H, 5.04\%; N, 14.01\%; found: C, 47.93\%; H, 5.08\%; N, 13.87\%. IR $\left(\mathrm{CHCl}_{3}\right), \mathrm{cm}^{-1}: 3683$ (NH-amide), $2975\left(\mathrm{CH}_{3}\right), 1675(\mathrm{C}=\mathrm{O}), 1550$ and $1520\left(\mathrm{NO}_{2}\right), 1319(\mathrm{~N}-$ $\mathrm{O}$ ); $\lambda_{\max } \mathrm{nm}$ in $\mathrm{CH}_{2} \mathrm{Cl}_{2}(\log \varepsilon): 424$ (1.77); $\mathrm{R}_{\mathrm{f}}=0.72$ (silica gel $\mathrm{GF}_{254}$ glass plates, methylene chloride-diethyl ether $8: 2 \mathrm{v} / \mathrm{v})$.

3b. yield $42 \%$; mp. $186-187^{\circ} \mathrm{C}$; ESI-MS $\mathrm{m} / \mathrm{z}\left([\mathrm{M}]^{+}\right)=398$; Elem. analysis: calcd. for $\mathrm{C}_{16} \mathrm{H}_{20} \mathrm{ClN}_{4} \mathrm{O}_{6}$ : C, 48.07\%; H, 5.04\%; N, 14.01\%; found: C, 47.98\%; H, 5.06\%; N, 13.91\%; IR $\left(\mathrm{CHCl}_{3}\right), \mathrm{cm}^{-1}: 3685$ (NH-amide), $2928\left(\mathrm{CH}_{3}\right), 1681(\mathrm{C}=\mathrm{O}), 1519$ and $1500\left(\mathrm{NO}_{2}\right), 1346(\mathrm{~N}-\mathrm{O})$; $\lambda_{\max } \mathrm{nm}$ in $\mathrm{CH}_{2} \mathrm{Cl}_{2}(\log \varepsilon): 348(2.50)$; $\mathrm{R}_{\mathrm{f}}=0.70$ (silica gel $\mathrm{GF}_{254}$ glass plates, methylene chloridediethyl ether $8: 2 \mathrm{v} / \mathrm{v})$. 
$N, N^{\prime}$-Bis(4-(2,2,6,6-tetramethylpiperidine-1-oxyl))-3,5-dinitro-4- and -2-aminobenzamide (4a and $\mathbf{4 b}$, respectively). were obtained in two variants as follows.

Variant A. To the acid chloride 3 in methylene chloride $(5 \mathrm{~mL} / \mathrm{g})$, triethylamine and 4-aminoTEMPO (in methylene chloride, $5 \mathrm{~mL} / \mathrm{g}$ ) were added in molar ratios 1:3: 2. The mixture became red and was stirred at room temperature for 3 days. Then the mixture was shaken sequentially (three times each) in a separatory funnel with $1 \mathrm{M}$ hydrochloric acid, aqueous $\mathrm{NaHCO}_{3}$, and water. After drying over anhydrous $\mathrm{Na}_{2} \mathrm{SO}_{4}$, the organic phase was evaporated under vacuum and the products were purified by preparative TLC as described above.

Variant B. The monoradicals $\mathbf{3 a}$ or $\mathbf{3 b}$ were converted into diradicals by treatment with with triethylamine and 4-amino-TEMPO (molar ratio 1:2.5:1.1) under the same conditions as described above.

4a. yield $65 \%$ for variant $\mathrm{A}$ and $57 \%$ for variant $\mathrm{B}$; mp. $121-122^{\circ} \mathrm{C}$; ESI-MS m/z $\left([\mathrm{M}]^{+}\right)=533$; Elem. analysis: calcd. for $\mathrm{C}_{25} \mathrm{H}_{38} \mathrm{~N}_{6} \mathrm{O}_{7}$ : C, 56.17\%; H, 7.16\%; N, 15,72\%; found: $\mathrm{C}, 56.12 \%$; $\mathrm{H}$, 7.11\%; N ,15.67\%; IR: $\left(\mathrm{CHCl}_{3}\right), \mathrm{cm}^{-1}: 3682$ (NH-amide), $2978\left(\mathrm{CH}_{3}\right), 1655(\mathrm{C}=\mathrm{O}), 1531$ and $1503\left(\mathrm{NO}_{2}\right), 1318(\mathrm{~N}-\mathrm{O})$; $\lambda_{\max } \mathrm{nm}$ in $\mathrm{CH}_{2} \mathrm{Cl}_{2}(\log \varepsilon)$ : 424 (3.62); $\mathrm{R}_{\mathrm{f}}=0.50$ (silica gel $\mathrm{GF}_{254}$ glass plates, methylene chloride-diethyl ether $8: 2 \mathrm{v} / \mathrm{v}$ ).

4b. yield $61 \%$ for variant $\mathrm{A}$ and $53 \%$ for variant $\mathrm{B}$; mp. $179-180^{\circ} \mathrm{C}$; ESI-MS m/z $\left(\left[\mathrm{M}^{+}\right)=533\right.$; Elem. anal.: calcd. for $\mathrm{C}_{25} \mathrm{H}_{38} \mathrm{~N}_{6} \mathrm{O}_{7}: \mathrm{C}, 56.17 \% ; \mathrm{H}, 7.16 \% ; \mathrm{N}, 15.72 \%$; found: $\mathrm{C}, 56.14 \%$; 7.10\%; N, $15.62 \%$; IR: $\left(\mathrm{CHCl}_{3}\right), \mathrm{cm}^{-1}: 3685$ (NH-amide), 3601 (NHamine), $2978\left(\mathrm{CH}_{3}\right), 1672$ $(\mathrm{C}=\mathrm{O}), 1508$ and $1458\left(\mathrm{NO}_{2}\right), 1332(\mathrm{~N}-\mathrm{O}) ; \lambda_{\max } \mathrm{nm}$ in $\mathrm{CH}_{2} \mathrm{Cl}_{2}(\log \varepsilon): 353(3.88) ; \mathrm{R}_{\mathrm{f}}=0.50$ (silica gel $\mathrm{GF}_{254}$ glass plates, methylene chloride-diethyl ether $8: 2 \mathrm{v} / \mathrm{v}$ ).

4- and 2-Methoxyamino-3,5-dinitro- $N$-(4-(2,2,6,6-tetramethyl-piperidine-1-oxyl)-benzamide)) (5a and 5b). respectively, were obtained by stirring the monoradicals 3 in methylene chloride $(25 \mathrm{~mL} / \mathrm{g})$ with triethylamine and solid methoxyamine hydrochloride in molar ratio 1:4:3 at room temperature for 5 days. The solution becomes rapidly blue for $\mathbf{5 a}$ and red for $\mathbf{5 b}$. On washing twice with $1 \mathrm{M}$ hydrochloric acid the solutions became yellow. The product was extracted into aqueous sodium hydroxide which became colored as described above. Then the aqueous layer was acidified rapidly with $1 \mathrm{M}$ hydrochloric acid and the product was extracted into methylene chloride. After drying over anhydrous $\mathrm{Na}_{2} \mathrm{SO}_{4}$, the organic phase was evaporated under vacuum and the products were purified by preparative TLC as described above. Product detection can be performed either by detection with UV light at $254 \mathrm{~nm}$, or by exposure to ammonia vapor when the two products become colored as indicated above.

5a. yield $63 \%$; mp. $173-75^{\circ} \mathrm{C}$; ESI-MS m/z $\left([\mathrm{M}]^{+}\right)=409$; Elem. Analysis: calcd. for $\mathrm{C}_{17} \mathrm{H}_{24} \mathrm{~N}_{5} \mathrm{O}_{7}$ : C, 49.75\%; H, 5.89\%; N, 17.06\%; found: C, 49.63\%; H, 5.92\%; N, 16.98\%; IR $\left(\mathrm{CHCl}_{3}\right), \mathrm{cm}^{-1}$ : 3684 (NH-amide), 3605 (NHOMe), $2926\left(\mathrm{CH}_{3}\right), 1655(\mathrm{C}=\mathrm{O}), 1543$ and $1510\left(\mathrm{NO}_{2}\right), 1320(\mathrm{~N}-$ O), 1064 (O-ether); $\lambda_{\max } \mathrm{nm}$ in $\mathrm{CH}_{2} \mathrm{Cl}_{2}\left(\log \varepsilon\right.$ ): 394 (3.47); $\mathrm{R}_{\mathrm{f}}=0.52$ (silica gel $\mathrm{GF}_{254}$ glass plates, methylene chloride-diethyl ether $8: 2 \mathrm{v} / \mathrm{v})$.

5b. yield 43\%; mp. $90-91^{\circ} \mathrm{C}$; ESI-MS m/z $\left([\mathrm{M}]^{+}\right)=409$; Elem. analysis: calcd. for $\mathrm{C}_{17} \mathrm{H}_{24} \mathrm{~N}_{5} \mathrm{O}_{7}$ : $\mathrm{C}$, 49.75\%; H, 5.89\%; N, 17.06\%; found:C, 49.68\%; H, 5.87\%; N, 16.93\%; IR $\left(\mathrm{CHCl}_{3}\right), \mathrm{cm}^{-1}: 3685$ (NH-amide), 3601 (NHOMe), $2979\left(\mathrm{CH}_{3}\right), 1671(\mathrm{C}=\mathrm{O}), 1514$ and $1455\left(\mathrm{NO}_{2}\right), 1336(\mathrm{~N}-\mathrm{O}) ; \lambda_{\max }$ 
nm in $\mathrm{CH}_{2} \mathrm{Cl}_{2}(\log \varepsilon): 342$ (3.3443); $\mathrm{R}_{\mathrm{f}}=0.49$ (silica gel $\mathrm{GF}_{254}$ glass plates, methylene chloridediethyl ether $8: 2 \mathrm{v} / \mathrm{v})$.

\section{1,3-Bis(4-aminooxy-3,5-dinitro- $N$-(4-(2,2,6,6-tetramethyl-piperidine-1-oxyl)benzamide)}

propane) (7a). was prepared by stirring for 5 days an acetonitrile solution of compound $\mathbf{3 a}$ with triethylamine and solid 1,3-bis(aminooxy)propane dihydrochloride in molar ratio 2:4:1. The color became yellow, green and then blue. Then a $1 \mathrm{M}$ solution was added to the resulting suspension till the color became yellow. After keeping in the refrigerator overnight, the precipitate was filtered off, washed on the filter with $1 \mathrm{M}$ hydrochloric acid, and dried over anh. $\mathrm{CaCl}_{2}$. Purification was effected by preparative TLC (silica gel $\mathrm{GF}_{254}$ glass plates, methylene chloride-diethyl ether $8: 2 \mathrm{v} / \mathrm{v}$ ).

7a. yield $36 \%$; mp. $135-36^{\circ} \mathrm{C}$; ESI-MS $\mathrm{m} / \mathrm{z}\left([\mathrm{M}-\mathrm{H}]^{+}\right)=831.1$ and $\left([\mathrm{M}+\mathrm{Na}]^{+}\right)=855.1$; Elem. analysis: calcd. for $\mathrm{C}_{35} \mathrm{H}_{48} \mathrm{~N}_{10} \mathrm{O}_{14}: \mathrm{C}, 50.48 \% ; \mathrm{H}, 5.81 \% ; \mathrm{N}, 16.82 \%$; found : $\mathrm{C}, 50.41 \%$; 5.77\%; N, 16.73\%; IR $\left(\mathrm{CHCl}_{3}\right), \mathrm{cm}^{-1}: 3693$ (NH-amide), $3026\left(\mathrm{CH}_{3}\right), 1602(\mathrm{C}=\mathrm{O}), 1545$ and $1510\left(\mathrm{NO}_{2}\right), 1320(\mathrm{~N}-\mathrm{O}) ; \lambda_{\max } \mathrm{nm}$ in $\mathrm{CH}_{2} \mathrm{Cl}_{2}(\log \varepsilon): 389$ (4.79); $\mathrm{R}_{\mathrm{f}}=0.17$ (silica gel $\mathrm{GF}_{254}$, methylene chloride-diethyl ether $8: 2 \mathrm{v} / \mathrm{v}$ ).

Visible absorption spectra for the colored anions 8a, 8b and 9a (Scheme 3) and for the hetero-diradical 6a (Scheme 1)

Weighed amounts of compounds $\mathbf{5 a}, \mathbf{5 b}$ or7a were dissolved in dichloromethane in a graduated flask, with triethylamine ( 2 molar equivalents of amine for $\mathbf{5 a}, \mathbf{b}$ and 3 molar equivalents for $\mathbf{7 a}$ ): $\lambda_{\max } \mathrm{nm}(\log \varepsilon)$ 8a, 561 (3.58); 8b, 488 (3.40); 9a, 573 (3.68). For the hetero-diradical 6a, a similar procedure was observed starting from $\mathbf{5 a}$ and $\mathrm{PbO}_{2}: \lambda_{\max }=509 \mathrm{~nm}$.

Oxidizing properties of $\mathbf{3 a}, \mathbf{b}, \mathbf{4 a}, \mathbf{b}, \mathbf{5 a}, \mathbf{b}$, and $7 \mathbf{a}$ were investigated qualitatively as follows. Compounds 13a-f and $\mathrm{DPPH}_{2}(\mathbf{1 5}, \mathrm{R}=\mathrm{H})$ were dissolved in dichloromethane and stirred for 30 min. with stoichiometric amounts of para-toluenesulfonic acid. Then two molar equivalents of compounds $\mathbf{3 a}, \mathbf{b}, \mathbf{4 a}, \mathbf{b}, \mathbf{5 a}, \mathbf{b}$, or $\mathbf{7 a}$ (but 3 molar equivalents for $\mathrm{DPPH}_{2}$ ) were added. After about 5 minutes the colour of the oxidation products started to appear, and these products were identified by TLC (silica gel $\mathrm{GF}_{254}$, toluene, twice) relative to standards $\mathbf{1 4 a - f}$ and DPPH, 16, R $=\mathrm{H}$ prepared independently. Also, DPPH was identified by its ESR spectrum.

\section{References}

1. Terrier, F. Nucleophilic Aromatic Displacement; VCH: New York, 1991.

2. Miller, J. Aromatic Nucleophilic Substitution; Elsevier: Amsterdam, 1968.

3. Covaci, I. C.; Constantinescu, T.; Caproiu, M. T.; Draghici, C.; Ionita, P.; Luca, C.; Stanciuc, G.; Maganu, M.; Balaban, A. T. Rev. Roum. Chim. 1999, 44, 333.

4. Covaci, I. C.; Constantinescu, T.; Caproiu, M. T.; Dumitrascu, F.; Luca C.; Balaban, A. T. Rev. Roum. Chim. 1999, 44, 531.

5. Covaci, I. C.; Ionita, P.; Caproiu, M. T.; Socoteanu, R.; Constantinescu, T.; Balaban, A. T. Central Eur. J. Chem. 2003, 1, 57. 
6. Kolehmainen, E.; Laihia, K.; Stanciuc, G.; Balaban, A. T. Rev. Roum. Chim. 1999, 44, 475.

7. Stanciuc, G.; Caproiu, M. T.; Caragheorgheopol, A.; Caldararu, H.; Balaban, A. T.; Walter, R. I. J. Magn. Reson. 1987, 75, 63.

8. Stanciuc, G.; Caproiu, M. T.; Caragheorgheopol, A.; Caldararu, H.; Constantinescu, T.; Balaban, A. T. Rev. Roum. Chim. 1989, 34, 1895.

9. Stanciuc, G.; Caproiu, M. T.; Caragheorgheopol, A.; Caldararu, H.; Constantinescu, T.; Balaban, A. T. Z. Naturforsch 1989, 44b, 1459.

10. Sumi, T. J.; Stanciuc, G.; Balaban, A. T.; Joela, H. Magn. Reson. Chem. 1996, 34, 197.

11. Sumi, T. J.; Stanciuc G.; Kasa, S.; Joela, H. Magn. Reson. Chem. 1995, 33, 511.

12. Stanciuc, G.; Balaban, A. T. Org. Prep. Proced. Internat. 1984, 16, 401.

13. Sisodia, S.; Martz, R. D.; Bosworth, N.; Lammert, G.; Reinheimer J. D. Can. J. Chem. 1980, 58,714 .

14. Linnett, J. W. J. Am. Chem. Soc. 1961, 83, 2643.

15. Linnett, J. W. The Electronic Structure of Molecules, $2^{\text {nd }}$ Edn; Methuen: London, 1972.

16. Caproiu, M. T.; Elian, M.; Grecu, N.; Negoita, N.; Balaban, A. T. J. Chem. Soc., Perkin Trans. II 1983, 591.

17. Forrester, A. R.; Hay, J. M.; Thomson, R. H. Organic Chemistry of Stable Free Radicals; Academic Press: London, 1968; p 180.

18. Suzuki, T.; Obi, K. Chem. Phys. Lett. 1995, 246, 130.

19. Szajdzinska-Pietek, E.; Wolszczak, M. Chem. Phys. Lett. 1997, 270, 527.

20. Bobbitt, J. M.; Guttermuth, M. C. F.; Ma, Z.; Tang, H. Heterocycles 1990, 30, 1131.

21. Ma, Z.; Bobbitt, J. M. J. Org. Chem. 1991, 56, 6110.

22. Merbouh, N.; Bobbitt, J. M.; Bruckner, C. Org. Prep. Proced. Internat. 2004, 36, 1.

23. Constantinescu, T.; Caproiu, M. T.; Zarna, N.; Caragheorgheopo, A.; Caldararu, H.; Stanciuc, G.; Radu, M.; Badescu, V.; Balaban, A. T., New. J. Chem 1997, 21, 575.

24. Covaci, I. C.; Constantinescu, T.; Caproiu, M. T.; Caldararu, H.; Ionita, P.; Balaban, A. T. Polish. J. Chem. 2001, 75, 1427.

25. Ionita, P.; Caproiu, M. T.; Luca, C.; Constantinescu, T.; Caldararu, H.; Balaban, A. T. J. Labelled Comp. Radiopharm. 1998, 41, 791.

26. Gille, L.; Prosch, U.; Stoesser, R. Radiat. Phys. Chem. 1992, 40, 461.

27. Currie, P. F.; Wilson, Q. J.; Rusk, A. C. M.; Weil, J. A, Can. J. Chem. 1983, 61, 1760.

28. Currie, P. F.; Wilson, Q. J.; Weil, J. A. Can. J. Chem. 1980, 58, 723.

29. Weil, J. A.; Sane, K. V.; Kinkade Jr. J. M. J. Phys. Chem. 1961, 65, 710.

30. Luca, C.; Ionita, P.; Constantinescu, T.; Caldararu, H.; Caragheorgheopol, A.; Caproiu, M. T. Rev. Roum. Chim. 1997, 42, 985.

31. Sykes, B. M.; Atwell, G. J.; Hogg, A.; Wilson, W. R.; O’Connor, C. J.; Denny, W. A. J. Med. Chem. 1999, 42, 346. 